\begin{tabular}{|c|l|}
\hline Title & Effect of honeycomb film on protein adsorption, cell adhesion and proliferation \\
\hline Author(s) & Sunami, Hiroshi; Ito, Emiko; Tanaka, Masaru; Y amamoto, Sadaaki; Shimomura, Masatsugu \\
\hline Citation & $\begin{array}{l}\text { Colloids and Surfaces. A, Physicochemical and Engineering A spects, 284 285, 548-551 } \\
\text { https://doi.org/10.1016/.Colsurfa.2005.11.041 }\end{array}$ \\
\hline Issue Date & $2006-08$-15 \\
\hline Doc URL & http://hdl.handle.net/2115/32751 \\
\hline Type & article (author version) \\
\hline File Information & sunami.pdf \\
\hline
\end{tabular}

Instructions for use 


\title{
Effect of honeycomb film on protein adsorption, cell adhesion and proliferation
}

\author{
Hiroshi SUNAMI ${ }^{1}$, Emiko ITO ${ }^{2}$, Masaru TANAKA ${ }^{1,2}$, Sadaaki \\ YAMAMOTO $^{1,2}$, Masatsugu SHIMOMURA ${ }^{2,3}$ \\ ${ }^{1}$ Creative Research Initiative "Sousei” (CRIS) Hokkaido University, \\ ${ }^{2}$ CREST, Japan Science and technology Corporation (JST), \\ ${ }^{3}$ Nanotechnology Research Center, Research Institute for Electronic \\ Science, Hokkaido University \\ E-mail address: sunami@poly.es.hokudai.ac.jp
}

\begin{abstract}
This article describes novel methods for controlling of cell adhesion by using micro porous polymer films. Recently we found the highly ordered micro porous films were formed when poly( $\varepsilon$-caprolactone)(PCL) solution was cast on substrates at high atmospheric humidity. The micro porous film has regular honeycomb morphology with a size of $5 \mu \mathrm{m}$ per cell (honeycomb film). Endothelial cells grew rapidly on the honeycomb film. After $24 \mathrm{~h}$ cell culture, the cell number on honeycomb films was lager than that on PCL flat films. In order to elucidate the effect of honeycomb films as a scaffold for cell culture, the adsorbed proteins on honeycomb films under cell culture condition were observed. After conditioning of the honeycomb film and the flat film in DMEM containing $10 \%$ foetal bovine serum (FBS) for $72 \mathrm{~h}$ at $37{ }^{\circ} \mathrm{C}$ in $5 \% \mathrm{CO}_{2}$ atmosphere, the adsorbed fibronectin-FITC and albumin-Texasred on the honeycomb films was observed by using confocal laser scanning microscope (CLSM). The observation revealed that fibronectin showed site-selective adsorption behavior on the honeycomb film. Albumin adsorbed on the honeycomb film non site-selectively, while fibronectin mainly adsorbed on inside of honeycomb pores. On the flat film, fibronectin was hardly observed. Since the honeycomb film accelerates the adsorption of fibronectin which is a typical protein as a cell adhesion molecule, the film could be a scaffold with excellent cell adhesion properties.
\end{abstract}

Keywords: Honeycomb film; Cell adhesion; Cell proliferation; Fibronectin; Tissue engineering; Self-organization.

\section{Introduction}


Cell behaviors such as growth, apoptosis and differentiation are controlled by micro-patterned cell adhesive surface [1-3]. Therefore, micro-patterning of cell adhesive regions attracts much attention. A large number of methods for preparing micro-patterned cell adhesive surface have been developed by photolithography and related techniques [1-18].

We have reported that micrometer size patterned polymer film (honeycomb film) can be prepared by self-organization [19]. The honeycomb film possessing a hexagonal array of micropores could be obtained by solution casting of various types of polymers on a solid substrate in a humid atmosphere. This method is simple and does not require special instrumentation in comparison with the photolithography method. Recently we reported that honeycomb film could be utilized for the micropatterned cell culture substrate [20-22]. The honeycomb film can modulate cell adhesion and concomitant behavior such as morphological change and expression of cell function [23-26]. In order to elucidate the effect of honeycomb films as a scaffold for cell culture, the adsorbed proteins on honeycomb films under cell culture condition were observed. Since adsorption of proteins on substrates is thought to be an initial process for cell adhesion and growth, it is important to reveal the protein adsorption on honeycomb film. In this research, adsorbed proteins on honeycomb films were determined by immunostaining, and their topological structure were observed by confocal laser scanning microscopy.

\section{Experiment}

The honeycomb film was fabricated by applying a moist air to a spread polymer solution containing biodegradable polymers (poly( $\varepsilon$-caprolactone)(PCL)) 1 and an amphiphilic polymer (co-carboxyhexyl acrylamide (CAP)) 2 (10:1 wt\%) (Scheme 1). A chloroform solution (5 $\mathrm{mg} / \mathrm{ml}$ ) containing PCL (MW=70,000-100,000) and CAP (MW=20,000) were used. Evaporative cooling lead to the formation of hexagonally-packed water droplets on the polymer solution. The honeycomb structure with pore diameter of $5 \mu \mathrm{m}$ and a wall thickness of $8 \mu \mathrm{m}$ was prepared on disk-type cover grass (ø15mm) (Figure 1). Flat films made from the same materials, were prepared as a reference. These honeycomb films and flat films were immersed in 1-propanol for 12 minutes to remove the CAP.

After conditioning (pre-incubation) of the honeycomb films and the flat films in Dulbecco's modified Eagle's minimal essential medium (DMEM; SIGMA Co. Ltd, St. Louis, MO, USA) supplemented with $10 \%$ heat-inactivated fetal bovine serum (FBS; Thermo Trace Ltd., Melbourne, Australia) and 1 \% Penicillin-Streptomycin (Gibco, Grand Island, NY, USA) for $72 \mathrm{~h}$ at $37{ }^{\circ} \mathrm{C}$ in $5 \% \mathrm{CO}_{2}$ atmosphere, adsorbed fibronectin-FITC and albumin-Texas red on the honeycomb films was observed in PBS by using confocal laser scanning microscope (FV-300, Olympus. Co., Tokyo, Japan). Fibronectin and albumin in the FBS previously were 
immunostained by anti-fibronectin FITC conjugate (Biogenesis Ltd., UK) and anti-albumin Texas red conjugate (Rockland immunochemicals, Inc., USA).

Porcine aortic endothelial cells (ECs, passage 2) were purchased from DAINIPPON PHARMACEUTICAL Co., Ltd. The honeycomb films and the flat films were insert to 24-well plates (IWAKI Microplate; IWAKI Glass Co., Funahashi, Japan). The ECs were used at passage 6 to seed the 24-well plate at a concentration of $1.5 \times 10^{4}$ cells $/ \mathrm{cm}^{2}$ (cells $/ \mathrm{ml}$ ) in $1 \mathrm{ml}$ DMEM supplemented with 10\% FBS and $1 \%$ Penicillin-Streptomycin. After $24 \mathrm{~h}$ the ECs culture, the number on the each substrate was evaluated with the Cell Proliferation Reagent WST-1 (F. Hoffmann-La Roche Ltd., Basel, Switzerland). All cell cultures were maintained in a humidified incubator at $37^{\circ} \mathrm{C}$ in $5 \% \mathrm{CO}_{2} / 95 \%$ air.

After $24 \mathrm{~h}$ on the substrates, cells were washed with PBS and fixed with $10 \%$ formalin in PBS for $10 \mathrm{~min}$. The cells were made permeable with $1 \%$ Triton-X for $30 \mathrm{~min}$, washed with $0.05 \%$ T-PBS for $5 \mathrm{~min}$, and incubated with a 1:100 dilution of mouse anti-vinculin monoclonal antibody (CHEMICON international, Inc., Temecula, CA, USA), respectively, for 90 min at 37 ${ }^{\circ}$ C. After washed with $0.05 \%$ T-PBS for 5 min, the cells were labeled with a 1:1000 dilutions of Alexa Fluor 546 rabbit anti-goat IgG (Molecular Probes, Inc., Eugene, OR, USA) in PBS for 60 min at $37{ }^{\circ} \mathrm{C}$ The cells were visualized with the confocal laser scanning microscope (FV-300, Olympus. Co., Tokyo, Japan).

\section{Results and Discussion}

After $72 \mathrm{~h}$ conditioning, the fluorescence images of the adsorbed fibronectin-FITC and the albumin-Texas red on the honeycomb films and the flat films are shown in Figure 2. The observation revealed that the fibronectins show characteristic adsorption behavior on the honeycomb film. However, the fibronectins (green points) hardly adsorbed on the flat films, the large amount of fibronectin adsorbed on the honeycomb film. Albumin (red points) adsorbed on the honeycomb film non site-selectively, while fibronectin mainly adsorbed on inside of honeycomb pores. It should be noted that clearly difference was observed for the adsorbed fibronectin structure between the honeycomb films and the flat films, although the surface chemical compositions are the same.

After $24 \mathrm{~h}$ incubation, the number of ECs on the honeycomb film was compared with that of ECs on the flat film (Figure 3). The cell number on the honeycomb films was nearly 4 times lager than that on the flat films. The honeycomb film is expected to be a good scaffold for an EC culture system, because the honeycomb film could accelerate the EC proliferation.

The cell proliferation is highly regulated by cell-adhesion behavior onto biomaterials. 
Focal adhesion, which plays a crucial role in cell-adhesion behavior, is major cellular sites responsible for cell-protein attachment. The focal adhesion points (vinculin cluster) are mainly observed in inside of honeycomb pores (Figure 4a). The site-selective distribution of focal adhesion points indicates that ECs adhere to adsorbed fibronectin molecules in the honeycomb pores. The morphology of focal adhesion points was clearly different between the honeycomb film (Figure 4b) and the flat film (Figure 4c), it was suggested that the difference of cell proliferation properties between these films is caused by the difference of focal adhesion points. The honeycomb film can control cell adhesion and proliferation by regulating the protein adsorption. This makes honeycomb film effective cell culture scaffold with high adhesion properties.

\section{Conclusion}

We reported that the site-selectively fibronectin adsorbed honeycomb film plays vital roles in cell adhesion and proliferation. The honeycomb film was demonstrated influencing cellular attachment and growth via the site-selective adsorption structure of fibronectin molecules. Hence, the honeycomb film could be an excellent scaffold with accelerating properties of cell adhesion and proliferation. These results indicate that a new method of controlling the protein adsorption, and, ultimately mediating cell adhesion and cell proliferation by using honeycomb film.

\section{Acknowledgement}

We are grateful for the funding for this work provided by "Special Coordination Funds for Promoting Science and Technology” of Ministry of Education, Culture, Sports, Science and Technology, and CREST, Japan Science and technology Corporation (JST).

\section{Reference}

[1] R. Singhvi, A. Kumar, G. P. Lopez, G. N. Stephanopoulos, D. I. C. Wang, G. M. Whitesides, and D. E. Ingber, Science 264 (1994) 696.

[2] C. S. Chen, M. Mrksich, S. Huang, G. M. Whitesides, and D. E. Ingber, Science 276 (1997) 1425.

[3] S. N. Bhatia, M. L. Yarmush, and M. Toner, J. Biomed. Mater. Res. 34 (1997) 189.

[4] B. Lom, K. E. Healy, and P. E. Hochberger, J. Neurosci. Methods 50 (1993) 385.

[5] D. V. Nicolau, T. Taguchi, H. Taniguchi, and S. Yoshikawa, Langmuir 15 (1999) 3845.

[6] S. P. A. Fodor, J. L. Read, M. C. Pirrung, L. Stryer, A. T. Lu, and D. Solas, Science 251 (1991) 767. 
[7] D. J. Pritchard, H. Morgan, and J. M. Cooper, Angew. Chem. Soc. 114 (1999) 4432.

[8] T. Matsuda and T. Sugawara, Langmuir 11 (1995) 2272.

[9] S. K. Bhatia, J. J. Hickman, and F. S. Ligler, J. Am. Chem. Soc., 114 (1992) 4432.

[10] D. A. Stenger, J. H. Georger, C. S. Dulcey, J. J. Hickman, A. S. Rudolph, T. B. Nielsen, S. M. McCort, and H. M. Calvert, J. Am. Chem. Soc. 114 (1992) 8435.

[11] C. S. Dulcey, J. H. J. Georger, V. Krauthamer, D. A. Stenger, T. L. Fare, and J. M. Calvert, Science 252 (1991) 551.

[12] M. Matsuzawa, K. Umemura, D. Beyer, K. Sugioka, and W. Knoll, Thin Solid Films 305 (1997) 74.

[13] J. Lahiri, E. Ostuni, and G. M. Whitesides, Langmuir 15 (1999) 2055.

[14] L. A. Kung, L. Kam, J. S. Hovis, and S. G. Boxer, Langmuir 16 (2000) 6773.

[15] A. Barnard, J. P. Penault, B. Michel, H. R. Bosshard, and E. Delamarche, Adv. Mater. 12 (2000) 1067.

[16] M.Mrksich and G. M. Whitesides, Annu. Rev. Biophys. Biomol. Struct. 25 (1996) 55.

[17] S. Takayama, J. C. McDonald, E. Ostuni, M. N. Liang, P. J. A. Kents, R. F. Ismaginov, and G. M. Whitesides, Proc. Natl. Acad. Sci. U.S.A. 96 (1999) 5545.

[18] E. Delamarche, A. Bernard, H. Schmid, B. Michel, and H. Biebuyck, Science 276 (1997) 779.

[19] N. Maruyama, T. Koito, J. Nishida, T. Sawadaishi, X. Cieren, K. Ijiro, O. Karthaus, and M. Shimomura, Thin Solid Films 327-329 (1998) 854.

[20] T. Nishikawa, J. Nishida, R. Ookura, S. Nishimura, S. Wada, T. Karino, M. Shimomura, Mater. Sci. Eng. C 8-9 (1999) 495.

[21] T. Nishikawa, J. Nishida, R. Ookura, S. Nishimura, S. Wada, T. Karino, M. Shimomura, Mater. Sci. Eng. C 10 (1999) 141-146.

[22] J. Nishida, K. Nishikawa, S. -I. Nishimura, S. Wada, T. Karino, T. Nishikawa, K. Ijiro, M. Shimomura, Polymer Journal 34(3) (2002) 166-174.

[23] Katsuhisa Sato, Masaru Tanaka, Masafumi Takebayashi, Kazutaka Nishikawa, Masatsugu Shimomura, International Journal of Nanoscience 1(5\&6) (2002) 689-693.

[24] Masaru Tanaka, Masafumi Takebayashi, Masashi Miyama, Jin Nishida and Masatsugu Shimomura, Bio-Medical Materials and Engineering 14 (2004) 439-446.

[25] A. Tsuruma, M. Tanaka, N. Fukushima, M. Shimomura, e-Journal of Surface Science and Nanotechnology 3 (2005) 159-164.

[26] T. Nishikawa, J. Nishida, K. Nishikawa, R. Ookura, H. Ookubo, H. Kamachi, M. 
Matsushita, S. Todo, M. Shimomura, Stud. Surf. Sci. Catal. 132 (2001) 509-512. 


\title{
Effect of honeycomb film on protein adsorption, cell adhesion and proliferation
}

\author{
Hiroshi SUNAMI ${ }^{1}$, Emiko ITO ${ }^{2}$, Masaru TANAKA ${ }^{1,2}$, Sadaaki \\ YAMAMOTO $^{1,2}$, Masatsugu SHIMOMURA ${ }^{2,3}$ \\ ${ }^{1}$ Creative Research Initiative "Sousei" (CRIS) Hokkaido University, \\ ${ }^{2}$ CREST, Japan Science and technology Corporation (JST), \\ ${ }^{3}$ Nanotechnology Research Center, Research Institute for Electronic \\ Science, Hokkaido University \\ E-mail address: sunami@poly.es.hokudai.ac.jp
}

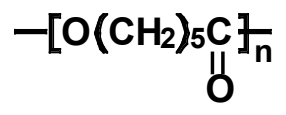

1 Poly( $\varepsilon$-caproractone)(PCL)

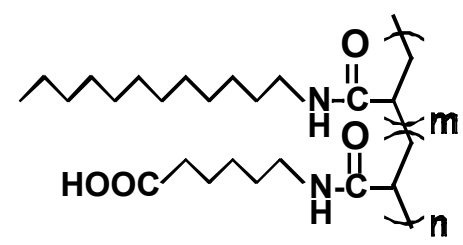

$\mathrm{m}: \mathrm{n}=4: 1$

2 Amphiphilic polymer (CAP)

Scheme 1

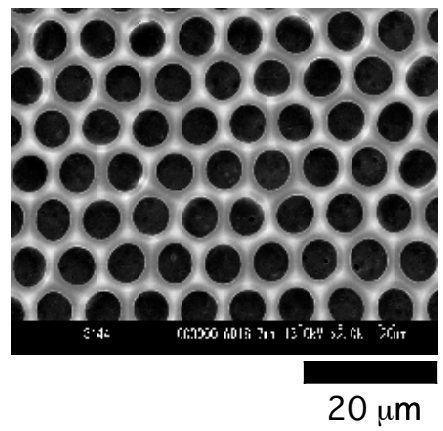

Figure 1 SEM image of Honeycomb film (PCL, pore size $5 \mu \mathrm{m}$ ). 

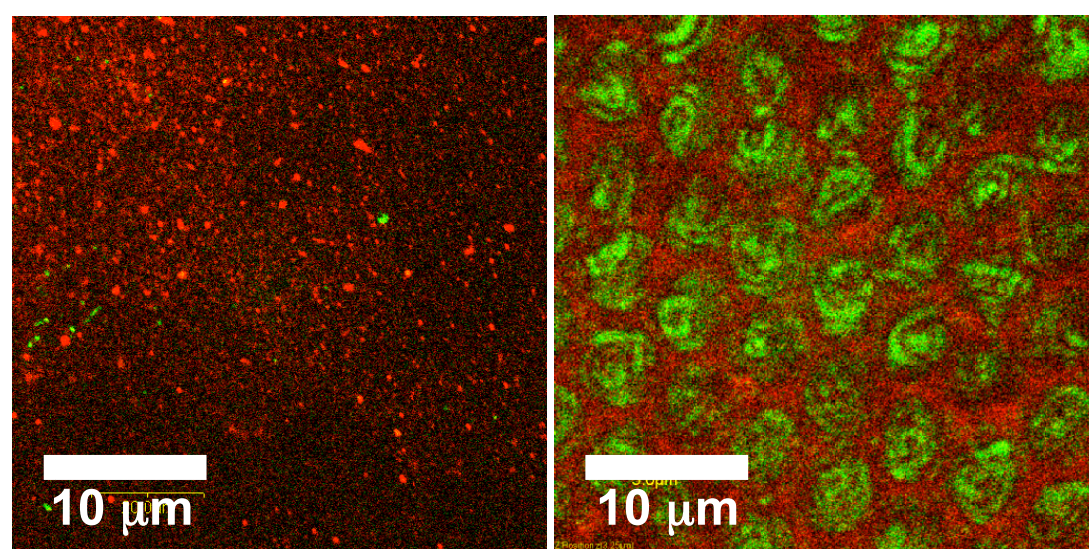

Figure 2 Fluorescence images of adsorbed protein after $72 \mathrm{~h}$ conditioning on flat film and on honeycomb film. Green points are adsorbed fibronectin. Red points are adsorbed albumin.

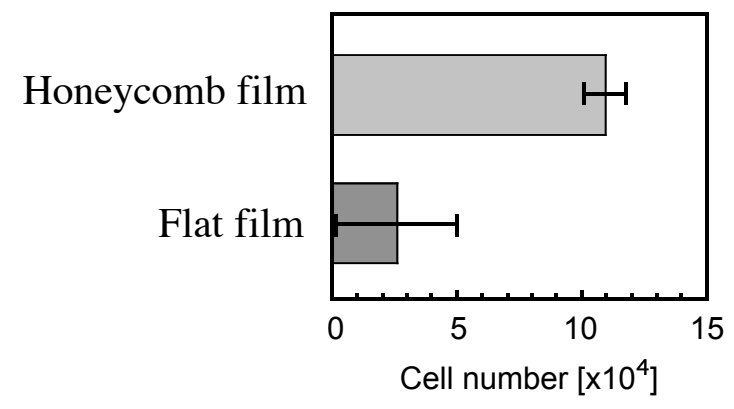

Figure 3 Number of ECs on honeycomb film and on flat film after $24 \mathrm{~h}$ incubation.

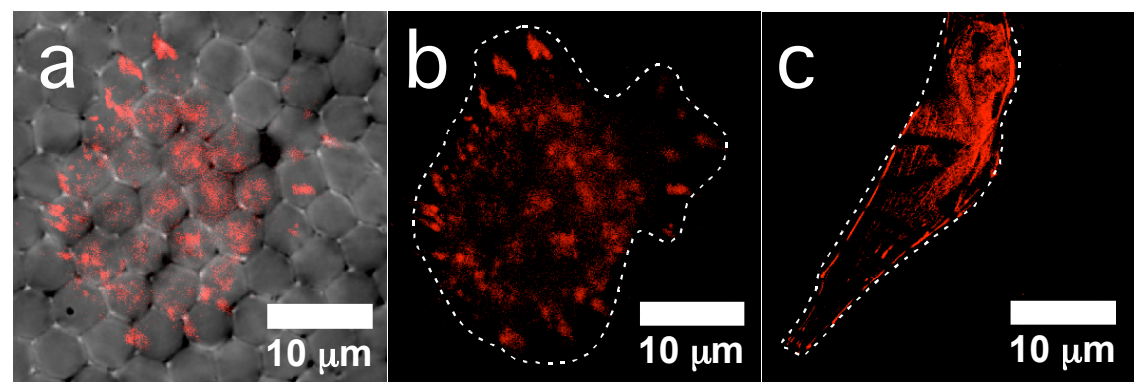

Figure 4 (a) Superposition image between differential interference image of honeycomb film and immnostained vinculin of EC on the honeycomb film. Comparison of focal adhesion points of EC between on (b) honeycomb film and (c) flat film. White dots are outline of an EC. Red points are immnostained vinculin cluster (Alexa Fluor 546). 